\title{
The frequency and fetomaternal outcomes of early-and late-onset preeclampsia: The experience of a single tertiary health center in the bustling metropolis of Turkey; Istanbul
}

\author{
Erken ve geç preeklampsinin sıklığı ve feto-maternal sonuçları: \\ Türkiye'nin kalabalık metropol kenti İstanbul'da bir üçüncü düzey \\ sağlık merkezinin deneyimleri
}

\author{
Halenur BOZDAĞ ${ }^{1}$, Fatma Bilge Selvi ÖĞÜTCÜOĞLU², Kadir GÜziN', Sedef Rukiye KABACA KILIÇ3, \\ Esra AKDENIZ DURAN ${ }^{4}$, illke TOPDAĞI AYDIN ${ }^{5}$, Ahmet GÖÇMEN ${ }^{6}$
}

\begin{abstract}
The purpose of the study is to determine the prevalence preeclampsia and to evaluate the maternal and the fetal adverse outcomes in the severe and the early-onset preeclampsia subgroups. Hundred and sixteen pregnant women with preclampsia who gave birth in an academic tertiary health centre were included in this study. The preeclampsia rate was 1.4 per 100 singleton births for three years (1.5/100 in 2012 and 1.3/100 in both 2013 and 2014 in this study). The rates of severe and early- onset preeclampsia were found as 0.5 and 0.4 per 100 singleton births in this three years period. Adverse maternal outcomes occurred in 18 cases. Maternal mortality occurred in 1 case. In severe preeclampsia (PE), the mean gestational age (33. week), birth weight (1935 g) and Apgar score at 5th minute at delivery (6.8 points) were calculated. In severe $P E$, the admission rate to Neonatal Intensive Care Unit (NICU) and neonatal mortality rate were 67 $\%$ and $24 \%$, respectively. In the early- onset preeclampsia, the mean birth weight and 5th min- Apgar score at delivery were found as $1454 \mathrm{~g}$ and 5.4 points, respectively. The admission rate to NICU and neonatal mortality rate were $91 \%$ and $\% 30$ in earlyonset $P E$, respectively. The rate of severe $P E$ in the early- onset $P E$ was 59\%. The women with severe preeclampsia had the highest antihypertensive drug prescribing rate (41\%) at discharge. Preeclampsia, particularly early- onset and severe preeclampsia require special attention of the healthcare providers.
\end{abstract}

Key words: Preeclampsia, early onset preeclampsia, severe preeclampsia, maternal outcome, neonatal outcome

\section{öz}

Çalışmanın amacı, preeklampsili kadınların prevelansını saptamak ve erken, ciddi preeklampsi alt gruplarında olumsuz sonuçları değerlendirmektir. Bu çalışma retrospektif tanımlayıcı kesitsel bir çalışma olarak gerçekleştirildi. Akademik 3. basamak bir merkezde doğum yapan 116 preeklampsili gebe kadın bu çalışmaya alındı. Çalışma sonuçları preeklampsi oranlarını üç yıl için 100 tekil doğumda 1.4, 2012 için 1,5, hem 2013 hem de 2014 için 1.3 olarak göstermektedir. Bu üç yıllık süreçte şiddetli ve erken başlangıçlı preeklampsi oranları 100 canlı tekil doğum başına 0,5 ve 0,4 olarak bulundu. Bir olguda ölüm ve 18 olguda anneye ait olumsuz sonuç gelişti. Ciddi preeklampside, ortalama gebelik yaşı, doğum kilosu ve doğumda 5. dk. apgar skoru sırasıyla 33 hafta, $1935 \mathrm{~g}$ ve 6,8 puan bulundu. Ciddi preeklampside, yenidoğan yoğun bakıma kabul oranı $\% 67$ ve yenidoğan ölüm oranları \%24'tür. Ortalama doğum ağırlığı ve doğumda 5. dk. apgar skoru, erken başlangıçlı preeklampside $1454 \mathrm{~g}$ ve 5,4 puan olarak bulundu. Yenidoğan yoğun bakıma kabul ve yenidoğan ölüm oranları erken başlangıçlı preeklampside \%91 ve \% 30'dur. Erken başlangıçlı preeklampsideki ciddi preeklampsi oranı \%59'dur. Ciddi preeklampsili kadınlar \%41 ile taburculukta en yüksek anti hipertansif ilaç önerilme oranına sahiptir. Preelampsili kadınlar, özellikle erken başlangıçlı ve ciddi preeklampsi sağlık sunucularının ayrıcaklı dikkatine gereksinim duyarlar.

Anahtar kelimeler: Preeklampsi, erken başlangıçlı preeklampsi, ciddi preeklampsi, anneye ait sonuçlar, yenidoğana ait sonuçlar

Received: 30.09 .2015

Accepted: 20.11 .2015

${ }^{1}$ Istanbul Medeniyet Üniversitesi Göztepe Eğitim ve Araştırma Hastanesi, Kadın Hastalıkları ve Doğum Bölümü

${ }^{2}$ Gölcük Necati Çelik Devlet Hastanesi, Kadın Hastalıkları ve Doğum Bölümü

${ }^{3}$ Nevşehir Devlet Hastanesi, Kadın Hastalıkları ve Doğum Bölümü

${ }^{4}$ İstanbul Medeniyet Üniversitesi, İstatistik Bölümü

${ }^{5}$ Malkara Devlet Hastanesi, Kadın Hastalıkları ve Doğum Bölümü

${ }^{6}$ İstanbul Medeniyet Üniversitesi Tıp Fakültesi Göztepe Eğitim ve Araştırma Hastanesi, Kadın Hastalıkları ve Doğum Bölümü

Yazışma adresi: Uzm. Dr. Halenur Bozdağ, Department of Obstetrics and Gynecology, Istanbul Medeniyet University Göztepe Teaching and Research Hospital, Istanbul, Turkey

e-mail: halenurbozdag@hotmail.com 


\section{INTRODUCTION}

Hypertensive Disorders in Pregnancy are categorized as chronic hypertension, gestational hypertension, preeclampsia and eclampsia ${ }^{1}$. The third global leading cause of major complications in childbirth was preeclampsia or eclampsia. World Health Organization reported that "There were 529000 annual maternal deaths worldwide. Hypertensive disorders of pregnancy were responsible for the death of 63000 and were the cause of $12 \%$ of maternal deaths." ${ }^{2}$. The prevalence of pre-eclampsia was reported as $2-8 \%$ of all pregnancies varying between countries, even between different ethnic groups living in same country ${ }^{3,4}$. According to a latest study, "the prevalence of preeclampsia changed over three decades (between 1980 and 2010), and preeclampsia had a tendency to shift from the mild to the severe preeclampsia" 5 .

Preeclampsia is described as a multisystem syndrome specific to human pregnancy and occurs as hypertension with new or worsening proteinuria after 20 weeks of gestation ${ }^{6,7}$. The inflammatory agents produced during the inadequate interactions are released to maternal systemic circulation and lead to systemic maternal inflammatory responses characterized by the activation of the coagulation cascade, and the injury of the vascular and the glomerular endothelial cells ${ }^{8,9}$.

The clinical symptoms occur as hypertension, proteinuria, neurologic disturbances, pulmonary oedema, hepatic dysfunction and thrombocytopenia. Preeclampsia is also a major threat for newborns as it leads to several problems related with intrauterine growth restriction, oligohydramnios, abnormal oxygenation and prematurity. Preeclamptic environment affects the women and their offsprings during pregnancy and maintains its influence on their health after birth. Several studies have reported that the women with preeclampsia can face with the increased risk of cardiovascular complications later in life ${ }^{10,11}$.

On the basis of this information, the women who have experienced preeclampsia in pregnancy are converted to a special group by the long- and shortterm consequences of preeclampsia. Particular attention should be paid to the needs of these women by healthcare providers. By knowing the incidence and clinical properties of preeclampsias, they can easily perform their outpatient follow-up when providing them preventive health care. We aimed to find out the rate of preeclampsia in our clinic and to analyze maternal and neonatal consequences as well as the clinical and laboratory characteristics of women with preeclampsia.

\section{MATERIAL and METHOD}

The study was carried out as retrospective, descriptive and cross-sectional trial by evaluating medical records. The patients with preeclampsia admitted to Istanbul Medeniyet University Göztepe Teaching and Research Hospital, Department of Obstetrics and Gynaecology between January 2012 and December 2014 were enrolled in the study. Local Ethics Committee approval was obtained for this study.

The diagnosis of preeclampsia (PE) and the definition of subgroups were based on the report of the American Congress of Obstetricians and Gynecologists Task Force on Hypertension in Pregnancy issued in $2013^{12}$. High blood pressure was defined as systolic blood pressure (SBP) of $\geq 140 \mathrm{mmHg}$ and/or diastolic blood pressure (DBP) of $\geq 90 \mathrm{mmHg}$ at at least two measurements with a minimal interval of 4 hours. Pregnant women who had high blood pressure at the admission of prenatal care or emergency unit were hospitalized for surveillance with the initial diagnosis of preeclampsia in the obstetric ward. The definition of preeclampsia was established as SBP of $\geq 140 \mathrm{mmHg}$ or DBP of $\geq 90 \mathrm{mmHg}$, after 20 weeks of pregnancy in previously normotensive pregnant women together with new-onset proteinuria or any severe features of preeclampsia such as "thrombocytopenia (platelet count less than 100.000/microliter)", "renal insufficiency (serum creatinine concentration greater than $1.1 \mathrm{mg} / \mathrm{dL}$ )", "impaired liver function(elevated liver enzymes to twice normal concentration, associated with epigastric or right upper-quadrant pain)", "pul- 
H. Bozdag et al., The frequency and fetomaternal outcomes of early-and late-onset preeclampsia: The experience of a single tertiary health center in the bustling metropolis of Turkey; Istanbul

monary oedema, new-onset cerebral or visual disturbance" according to ACOG 2013 parameters ${ }^{12}$. Proteinuria was defined dipstick reading of $\geq 1(+)$ protein in urine.

All the PE cases were divided into two groups, based on the severity of the clinical symptoms; severe $\mathrm{PE}$ and preeclampsia without severe features. For all the PE cases there was another division which could be stated as early-onset and late-onset preeclampsia, based on the disease onset. The severe form of preeclampsia was defined as SBP $\geq 160 \mathrm{mmHg}$ or DBP $\geq 110 \mathrm{mmHg}$ along with the presence of other severe features of preeclampsia that were mentioned above. If the clinical symptoms and the delivery occur before 34 weeks of pregnancy, it was identified as early-onset PE. The definition of late-onset PE was made when manifestations occur after 34 weeks.

Information about maternal age, parity, laboratory parameters such as serum creatinine, platelet count, aspartate transaminase (AST), alanine transaminase (ALT), level of urinary protein with dipstick reading at the time of admission, clinical symptoms and demographic properties of preeclamptic patients were obtained from their medical records. The information about previous chronic diseases such as, chronic hypertension, renal disease and diabetes mellitus were also collected and recorded.

Furthermore, maternal adverse outcomes were defined as abruption of placenta, disseminated coagulopathy, eclampsia, need for blood transfusion due to obstetric haemorrhage, longevity of hospital stay, and maternal mortality.

When the patient had high blood pressure at discharge, antihypertensive drugs such as methyl-dopa, nifedipine, metoprolol tablet or drug combination were prescribed. Drug combination consisted of methyl-dopa and nifedipine tablet or methyl-dopa and metoprolol tablet. Drugs prescribed at discharge was also included in the evaluation.

The gestational age was estimated with the last menstrual period (LMP) and was confirmed by the first trimester sonogram. Small for gestational age (SGA) was defined as the newborn who had a lower birth weight within $10^{\text {th }}$ percentile of the weight adjusted for its gestational age. Intrauterine growth restriction (IUGR) is entitled to a foetus with an estimated foetal weight $<10^{\text {th }}$ percentile of its gestational age -adjusted weight as detected on ultrasound. Low Apgar scores were defined as less than 7 points estimated at the $5^{\text {th }}$ minute of life. Apgar scores at the $5^{\text {th }}$ minute were recorded. Neonatal mortality was defined as death occurred during the neonatal period, that is up to 28 days after live birth at or after 22 completed weeks of gestation. Information about foetal outcomes such as Apgar scores at birth, need for neonatal intensive care unit (NICU), birth weight, neonatal death were obtained and recorded. The presence of any signs of maternal or foetal adverse outcomes were accepted as poor obstetric outcome.

The data were analyzed using SAS software. The categorical data were presented as $\mathrm{n}(\%)$, whereas continuous variables as mean ( \pm standard deviation). The associations between two or more categorical variables were tested using the chi-square test with appropriate correction. If the data were normally distributed, the two-sample t-test was used to determine the differences between the mean of two different groups; otherwise, Mann-Whitney $U$ test was used to test the significance between two variables. A difference between two values was considered as significant if $p$-value was $<0.05$.

\section{RESULTS}

In three years period from January 2012 to December 2014 , the number of all births in the hospital was 8.205 of which 178 of them were admitted to obstetric ward with initial diagnosis of preeclampsia but only 116 fulfilled the preefined criteria of preeclampsia. The data of the patients with preeclampsia in this 3-year-period were evaluated in this hospital-based study. We found that the preeclampsia rate was 1.4 per 100 singleton births in three years and varied as 1.5/100 in 2012, $1.3 / 100$ in 2013, and 1.3/100 in 2014. 
Forty-three pregnant women had properties of severe preeclampsia (37\%) and 73 cases (62\%) did not have symptoms of severe preeclampsia. Early-onset preeclampsia was diagnosed in 34 cases (29\%), while 82 patients $(71 \%)$ had late- onset PE. The frequency of severe PE and early- onset PE were found as 0.5 and 0.4 per 100 singleton births in three years period. The proportion of severe PE in early- onset disease was documented for 20 of 34 cases (59\%) and severe PE in late-onset PE was seen in 23 of the 82 cases (28\%).

Table 1. General characteristics of study group (n:116).

\begin{tabular}{lcc}
\hline & Mean (士SD) & Min-Max \\
\hline Age (year) & $29.33(6.04)$ & $16-46$ \\
Gestational age at diagnosis (wk) & $35.32(3.94)$ & $23-41$ \\
Gestational age at delivery (wk) & $35.36(3.90)$ & $23-41$ \\
Maximal SBP ${ }^{1}$ at admission (mm/Hg) & $160.42(21.84)$ & $125-220$ \\
Maximal DBP ${ }^{2}$ at admission (mm/Hg) & $100.95(12.70)$ & $80-150$ \\
\hline & $\mathrm{n}$ & $\%$ \\
\hline Primiparity & 65 & 56 \\
Multiparity & 51 & 44 \\
Previous history of preeclampsia & 6 & 5 \\
Prescribing antihypertensive drug at & 40 & 34 \\
discharge $\quad$ Methyl-dopa tablet & 16 & 40 \\
$\quad$ Nifedipine tablet & 7 & 17.5 \\
$\quad$ Metoprolol tablet & 7 & 17.5 \\
$\quad$ Drug combination & 10 & 10 \\
Maternal complications & 18 & 14 \\
Perinatal outcome & & \\
\hline & & \\
\hline
\end{tabular}

${ }^{1}$ systolic blood pressure, ${ }^{2}$ diastolic blood pressure, ${ }^{3}$ Intrauterine growth restriction, ${ }^{4}$ Small for gestational age, ${ }^{5}$ Neonatal Intensive Care Unit

Demografic and clinical data of the study population are presented in Table 1 . The mean age of all cases was 29 years and $55 \%$ of them were primipara.

Maternal adverse outcomes occurred in 18 cases, while 6 of them were diagnosed as placental abruption and 2 had seizures of eclampsia. The need for blood transfusion ( $\mathrm{n}: 9)$ was the most common maternal obstetric adverse outcome. Maternal mortality occurred in one case diagnosed as disseminated intravascular coagulation and haemolysis/elevated liver enzymes/low platelets (HELLP) syndrome.

Antihypertensive drugs were prescribed for $40 \%$ of the patients at discharge (Table 1). Antihypertensive drugs were prescribed for $35 \%$ of the whole study population [early-onset preeclampsia (12/34) and the early-onset with severe preeclampsia group (7/20)]. Most frequently $(41 \% ; 18 / 43)$ women with severe preeclampsia were prescribed antihypertensive drug.

The most common adverse foetal outcomes were the requirement of NICU, low Apgar score and neonatal death. The mean birth weight was $2387 \mathrm{~g}$ and SGA and IUGR were found in $9 \%(n: 11)$ and $10 \%(n: 12)$ of the newborns, respectively. Neonatal mortality rate in three years period was documented as 1.58 in 1.000 live births (Number of neonatal deaths x 1000/ Total number of live births).

The preeclampsia group with serious symptoms had higher SBP and DBP than the group without severe preeclampsia. In terms of blood pressure, there were no statistical differences between late-onset and early- onset preeclampsia groups.

Liver enzymes such as AST, ALT and proteinuria were significantly higher in the early-onset and serious preeclampsia group when compared with the lateonset and the preeclampsia group without severe manifestations.

The mean gestational age at diagnosis was demonstrated as 33 weeks in the severe preeclampsia group and was significantly lower than the group with preeclampsia without severe symptoms.

In view of the interval between the diagnosis and the delivery, there were significant differences between the early-onset preeclampsia (1.79 day) and the late- 
H. Bozdag et al., The frequency and fetomaternal outcomes of early-and late-onset preeclampsia: The experience of a single tertiary health center in the bustling metropolis of Turkey; Istanbul

Table 2. Maternal and neonatal outcome in the preeclampsia subgroups.

\begin{tabular}{|c|c|c|c|c|c|c|}
\hline & $\begin{array}{c}\text { Early-onset } \\
\text { preeclampsia } \\
\mathrm{N}: 34\end{array}$ & $\begin{array}{c}\text { Late-onset } \\
\text { preeclampsia } \\
\mathrm{N}: 82\end{array}$ & p-value & $\begin{array}{c}\text { Severe } \\
\text { preeclampsia } \\
\mathrm{N}: 43\end{array}$ & $\begin{array}{c}\text { Without severe } \\
\text { features preeclampsia } \\
\mathrm{N}: 73\end{array}$ & p-value \\
\hline \multicolumn{7}{|l|}{ At diagnosis of PreEclampsia } \\
\hline $\mathrm{SBP}^{1} \mathrm{~mm} \mathrm{Hg}( \pm \mathrm{SD})$ & $159.27(23.87)$ & $157.71(32.31)$ & 0.60 & $167.09(22.76)$ & $152.97(32.532)$ & 0.02 \\
\hline $\mathrm{DBP}^{2} \mathrm{~mm} \mathrm{Hg}( \pm \mathrm{SD})$ & $131.32(12.51)$ & $131.75(15.55)$ & 0.93 & $104.77(14.31)$ & $98.85(11.15)$ & 0.03 \\
\hline $\mathrm{ALT}^{3}$ Level U/L ( $\left.\pm \mathrm{SD}\right)$ & $38.21(46.77)$ & $20.12(31.16)$ & 0.003 & $40.47(54.28)$ & $16.61(16.74)$ & 0.03 \\
\hline $\mathrm{AST}^{4} \mathrm{U} / \mathrm{L}$ Level$( \pm \mathrm{SD})$ & $62.14(92.68)$ & $31.77(43.62)$ & 0.01 & 64.54 (97.09) & 26.69 (19.19) & 0.01 \\
\hline Proteinuria dipstick ( \pm SD) & $3(2.20)$ & $2.51(1.88)$ & 0.27 & $3.51(2.14)$ & $2.15(1.71)$ & 0.002 \\
\hline Gestational age week ( \pm SD) & $30.32(2.56)$ & $37.45(1.95)$ & 0.001 & $33.84(4.15)$ & $36.27(3.44)$ & 0.001 \\
\hline Time from diagnosis to delivery/day $( \pm S D)$ & $1.79(4.10)$ & $0.52(1.19)$ & 0.001 & $1.30(3.73)$ & $0.65(1.27)$ & 0.81 \\
\hline Time to discharge from delivery/day $( \pm S D)$ & $4.56(1.37)$ & $3.58(1.70)$ & 0.0001 & $4.39(2.01)$ & $3.55(1.36)$ & 0.007 \\
\hline \multicolumn{7}{|l|}{ Fetal outcome } \\
\hline APGAR $5^{\text {th }} \min ( \pm S D)$ & $5.4(2,9)$ & $8.9(1,9)$ & 0.0001 & $6.8(3,2)$ & $8.6(2,3)$ & 0.0003 \\
\hline Birthweight g $( \pm S D)$ & $1454(537.68)$ & $2776(701.78)$ & 0.0001 & $1935(814.13)$ & $2667.29(828.16)$ & 0.001 \\
\hline Need NICU $\mathrm{n}(\%)$ & 31 (91\%) & $28(34 \%)$ & 0.0001 & $29(67 \%)$ & $30(40 \%)$ & 0.009 \\
\hline Death $n(\%)$ & $10(30 \%)$ & $3(4 \%)$ & 0.0001 & $9(24 \%)$ & $4(5 \%)$ & 0.01 \\
\hline
\end{tabular}

${ }^{1}$ systolic blood pressure, ${ }^{2}$ diastolic blood pressure, ${ }^{3}$ Alanine transaminase, ${ }^{4}$ Aspartate transaminase, ${ }^{5}$ Neonatal Intensive Care Unit Continuous variables are tabulated as mean ( $\pm S D$ ) and categorical variables are tabulated as $n(\%)$.

Continuous variables were compared by ANOVA or Kruskal-Wallis, and categorical variables by chi-square.

onset preeclampsia group (0.52 day). The duration of hospital stay was found longer in the early-onset group than the late-onset group. Also this period was longer in the severe preeclampsia group when compared with preeclampsia group without severe features.

In terms of perinatal outcomes, the birth weight and the Apgar score at the $5^{\text {th }}$ minute were significantly lower in neonate who were born to a mother with early-onset and with severe preeclampsia. Also the rate of neonatal death was $30 \%$ ( $n: 10)$ in women with early-onset and $24 \%(n: 9)$ in severe preeclampsia.

In comparison with the late-onset PE group and the $P E$ group without severe features, the rate of neonatal death was appeared to be significantly higher in the early-onset PE group and in the severe PE group.

Ninety-one percent of women with early- onset preeclampsia needed NICU which was significantly higher when compared with women with late-onset preeclampsia. The frequency of need for NICU was $67 \%$ for severe preeclampsia group and was $40 \%$ for the group with preeclampsia without severe features. There was a statistically significant difference between these two groups.
The data of the study groups related with maternal clinical outcomes and neonatal outcomes are presented in Table 2.

\section{DISCUSSION}

The prevalence of preeclampsia continues to be one of the unresolved questions in the epidemiology. The overall prevalence of preeclampsia ranges between $5-10 \%$ globally ${ }^{2}$. In industrialized countries, it was reported between 3 to $5 \%{ }^{13,14}$. Although the exact prevalence of preeclampsia in low- and middle- income countries is unknown, it is reported as $9.1 \%$ in both Africa and Asia, $25.7 \%$ in both Latin America and the Caribbean Countries while it is $2.13 \%$ in Southern Iran, respectively ${ }^{15,16}$. In United States, between 1980 and 2010 the rate of preeclampsia was $3.4 \%$. Researchers also reported that "the rate of severe pre-eclampsia in 1980 increased from $0.3 \%$ to $1.4 \%$ in 2010 , in contrast, mild pre-eclampsia in 1980 declined from 3.1\% to $2.5 \%$ in 2010 ". In view of severe and early preeclampsia, the prevalence of severe pre-eclampsia was reported as $\mathbf{1 . 7 \%}$ in Nova Scotia and as 29.3 per 10.000 deliveries in Singapore ${ }^{17,18}$. In another study, the rates of early and late preeclampsia were reported as $0.3 \%$ and $2.7 \%$, respectively (preeclampsia rate was 3.0 per 100 singleton births) $)^{18}$. 
Compared with the results reported by other centres, a lower rate of preeclampsia obtained in our academic tertiary health centres was unexpected. But the rate of severe and early preeclampsia in this study was consistent with the data reported in other studies. It was explained that especially high risk group of patients were referred to our tertiary health centres. The disease had a lower incidence but the proportion of high risk group patients were high.

Nulliparity is a risk factor for preeclampsia and is based on the primipaternity hypothesis. We found that over half of the cases (55\%) were primipara women as it was recorded in other studies, and the mean age of the study population was 29 years ${ }^{21,22}$.

The maternal or perinatal outcomes were affected significantly by preeclampsia. The women with preeclampsia had higher risk of severe maternal morbidity and mortality, by comparison with pregnant women without preeclampsia ${ }^{20,21}$. Also obstetrical adverse outcomes depend on gestational age at diagnosis, severity of preeclampsia, suitable management of the disease and the preexisting medical diseases ${ }^{18,22,24}$. When the gestational age at diagnosis was less than 32 weeks, the disease was associated with 20-fold increased risk of maternal mortality, compared with that at $\geq 37$ weeks $^{19,25}$. Women with severe disease were more likely to deliver premature and lower birth weight babies ${ }^{22}$.

The average of gestational age of severe preeclampsia in our study was 33 weeks. The vast majority of earlyonset preeclampsia had properties of severe preeclampsia, so the proportion of severe preeclampsia in early- onset preeclampsia was found to be high. Therefore, management of preeclampsia far from term comes up as a challenging issue for us and also for other clinicians. Meta-analyses demonstrated that "Expectant management of women with early- onset preeclampsia is associated with a lower incidence of some neonatal morbidity, without significant differences in maternal outcomes." ${ }^{26}$. In the absence of worsening maternal condition, we have preferred to use expectant approach for preeclampsia far from term. The results obtained in this study verified the assumption which states that "the duration from diagnosis to delivery was longer in early- onset preeclampsia". This result demonstrated that early and severe preeclampsia groups were in need of medical support for much longer time because of the severity of their clinical condition. The rate of prescribing antihypertensive drugs at discharge were found as $35 \%$ and $41 \%$ in these two groups. What we inferred from these results was that these patients were in need of a long and a continuing medical support.

The presence of preeclampsia has been linked with poor perinatal outcomes such as IUGR, low birth weight, low Apgar score at $5^{\text {th }}$ min, increased requirement for NICU stay,and neonatal deaths. Latest studies have reported higher rates of admission to NICU had among babies born to women with preeclampsia. Increasing number of premature deliveries in preeclampsia is the most important reason for the requirement for hospitalization in NICU. But, adverse neonatal outcomes are not limited to preterm delivery in preeclampsia. Neonatal thrombocytopenia, neutropenia and bronchopulmonary dysplasia could be accompanied by maternal preeclampsia as well as others that are mentioned above $e^{20,27-29}$. In this study, admission to NICU has the highest percentage among. Also IUGR, low birth weight babies and neonatal mortality were more frequently seen among preeclamptic women with adverse perinatal outcomes as emphasized in several studies ${ }^{30-32}$.

Preeclampsia, particularly early-onset preeclampsia and severe preeclampsia are associated with adverse maternal and neonatal outcomes. Also, in the light of previous studies; preeclampsia, and early- onset and severe preeclampsia subgroups are associated with long term cardiovascular risk. To identify the population of women with preeclampsia in secondary or tertiary health centres and to provide their integration with primary healthcare providers are necessary issues for the early detection of cardiovascular diseases. 
H. Bozdag et al., The frequency and fetomaternal outcomes of early-and late-onset preeclampsia: The experience of a single tertiary health center in the bustling metropolis of Turkey; Istanbul

\section{REFERENCES}

1. Wallis AB, Saftlas AF, Hsia J, et al. Secular trends in the rates of preeclampsia, eclampsia, and gestational hypertension, United States, 1987-2004. Am J Hypertens 2008;21(5):521-6. http://dx.doi.org/10.1038/ajh.2008.20

2. Khan KS, Wojdyla D, Say L, et al. WHO analysis of causes of maternal death: a systematic review. Lancet 2006;367(9516):1066-74. http://dx.doi.org/10.1016/S0140-6736(06)68397-9

3. Duley L. The global impact of pre-eclampsia and eclampsia. Semin Perinatol 2009;33(3):130-7. http://dx.doi.org/10.1053/j.semperi.2009.02.010

4. Naimy Z, Grytten J, Monkerud L, et al. The prevalence of preeclampsia in migrant relative to native Norwegian women: a population-based study. BJOG, 2014.

5. Ananth CV, Keyes KM, Wapner RJ. Pre-eclampsia rates in the United States, 1980-2010: age-period-cohort analysis. Bmj 2013;347:f6564.

http://dx.doi.org/10.1136/bmj.f6564

6. Turner JA. Diagnosis and management of pre-eclampsia: an update. International Journal of Women's Health 2010;2:327-37. http://dx.doi.org/10.2147/IJWH.S8550

7. Sibai B, Dekker G, Kupferminc M. Pre-eclampsia. Lancet 2005;365(9461):785-99. http://dx.doi.org/10.1016/S0140-6736(05)71003-5

8. Faas MM, Spaans F, De Vos P. Monocytes and macrophages in pregnancy and pre-eclampsia. Front Immunol 2014;5:298. http://dx.doi.org/10.3389/fimmu.2014.00298

9. Guzin K, Tomruk S, Tuncay YA, et al. The relation of increased uterine artery blood flow resistance and impaired trophoblast invasion in pre-eclamptic pregnancies. Arch Gynecol Obstet 2005;272(4):283-8.

http://dx.doi.org/10.1007/s00404-005-0005-2

10. Haukkamaa L, Salminen M, Laivuori H, et al. Risk for subsequent coronary artery disease after preeclampsia. Am J Cardiol 2004;93(6):805-8. http://dx.doi.org/10.1016/j.amjcard.2003.11.065

11. Wilson BJ, Watson MS, Prescott GJ, et al. Hypertensive diseases of pregnancy and risk of hypertension and stroke in later life: results from cohort study. Bmj 2003;326(7394):845. http://dx.doi.org/10.1136/bmj.326.7394.845

12. American College of O, Gynecologists, Task Force on Hypertension in P. Hypertension in pregnancy. Report of the American College of Obstetricians and Gynecologists' Task Force on Hypertension in Pregnancy. Obstetrics and Gynecology 2013;122(5):1122-31.

13. Dahlstrom BL, Engh ME, Bukholm G, et al. Changes in the prevalence of pre-eclampsia in Akershus County and the rest of Norway during the past 35 years. Acta Obstetricia et Gynecologica Scandinavica 2006;85(8):916-21.

http://dx.doi.org/10.1080/00016340500442449

14. Rudra CB, Williams MA. Monthly variation in preeclampsia prevalence: Washington State, 1987-2001. The journal of maternal-fetal \& neonatal medicine : the official journal of the European Association of Perinatal Medicine, the Federation of Asia and Oceania Perinatal Societies, the International Society of Perinatal Obstet 2005;18(5):319-24. http://dx.doi.org/10.1080/14767050500275838

15. Firoz T, Sanghvi $H$, Merialdi $M$, et al. Pre-eclampsia in low and middle income countries. Best Practice \& Research Clinical Obstetrics \& Gynaecology 2011;25(4):537-48. http://dx.doi.org/10.1016/j.bpobgyn.2011.04.002

16. Zibaeenezhad M, Ghodsi M, Arab P, et al. The Prevalence of Hypertensive Disorders of Pregnancy in Shiraz, Southern Iran. Iranian Cardiovascular Research Journal 2010.
17. Ananth CV, Savitz DA, Luther ER, et al. Preeclampsia and preterm birth subtypes in Nova Scotia, 1986 to 1992. American Journal of Perinatology 1997;14(1):17-23. http://dx.doi.org/10.1055/s-2007-994090

18. Loi K, Khoo CK, Tan KH, et al. A review of 93 cases of severe preeclampsia in Singapore: are there risk factors for complications? Singapore Medical Journal 2007;48(9):808-12.

19. Lisonkova S, Sabr Y, Mayer C, et al. Maternal morbidity associated with early-onset and late-onset preeclampsia. Obstetrics and Gynecology 2014;124(4):771-81. http://dx.doi.org/10.1097/AOG.0000000000000472

20. Wolde Z, Segni H, Woldie M. Hypertensive disorders of pregnancy in jimma university specialized hospital. Ethiopian Journal of Health Sciences 2011;21(3):147-54.

21. Prakash J, Vohra R, Pandey LK, et al. Spectrum of kidney diseases in patients with preeclampsia-eclampsia. The Journal of the Association of Physicians of India 2010;58:543-6.

22. Guzin K, Goynumer G, Gokdagli F, et al. The effect of magnesium sulfate treatment on blood biochemistry and bleeding time in patients with severe preeclampsia. J Matern Fetal Neonatal Med 2010;23(5):399-402. http://dx.doi.org/10.3109/14767050903156684

23. Von Dadelszen P, Payne B, Li J, et al. Prediction of adverse maternal outcomes in pre-eclampsia: development and validation of the fullPIERS model. Lancet 2011;377(9761):21927.

http://dx.doi.org/10.1016/S0140-6736(10)61351-7

24. Gaugler-Senden IP, Berends AL, de Groot CJ, et al. Severe, very early onset preeclampsia: subsequent pregnancies and future parental cardiovascular health. Eur J Obstet Gynecol Reprod Biol 2008;140(2):171-7. http://dx.doi.org/10.1016/j.ejogrb.2008.03.004

25. Steegers EA, von Dadelszen P, Duvekot JJ, et al. Pre-eclampsia. Lancet 2010;376(9741):631-44. http://dx.doi.org/10.1016/S0140-6736(10)60279-6

26. Churchill D, Duley L, Thornton JG, et al. Interventionist versus expectant care for severe pre-eclampsia between 24 and 34 weeks' gestation. The Cochrane Database of Systematic Reviews 2013;7:CD003106. http://dx.doi.org/10.1002/14651858.cd003106.pub2

27. Sachan R, Patel ML, Sachan P, et al. Outcomes in hypertensive disorders of pregnancy in the North Indian population. International Journal of Women's Health 2013;5:101-8. http://dx.doi.org/10.2147/IJWH.S40473

28. Fatemeh T, Marziyeh G, Nayereh G, et al. Maternal and perinatal outcome in nulliparious women complicated with pregnancy hypertension. JPMA The Journal of the Pakistan Medical Association 2010;60(9):707-10.

29. Yucesoy G, Ozkan S, Bodur H, et al. Maternal and perinatal outcome in pregnancies complicated with hypertensive disorder of pregnancy: a seven year experience of a tertiary care center. Archives of Gynecology and Obstetrics 2005;273(1):43-9. http://dx.doi.org/10.1007/s00404-005-0741-3

30. Nadkarni J, BahlJ, Parekh P. Perinatal outcome in pregnancy associated hypertension. Indian Pediatrics 2001;38(2):174-8.

31. Ayaz A, Muhammad T, Hussain SA, et al. Neonatal outcome in pre-eclamptic patients. Journal of Ayub Medical College, Abbottabad: JAMC 2009;21(2):53-5.

32. Buchbinder A, Sibai BM, Caritis $S$, et al. Adverse perinatal outcomes are significantly higher in severe gestational hypertension than in mild preeclampsia. American Journal of Obstetrics and Gynecology 2002;186(1):66-71. http://dx.doi.org/10.1067/mob.2002.120080 